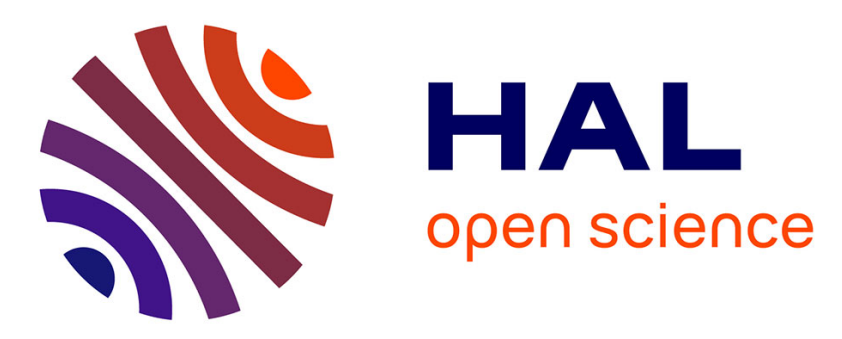

\title{
A climatic chamber experiment to test the short term effect of increasing temperature on branched GDGT distribution in Sphagnum peat
}

Arnaud Huguet, Andre-Jean Francez, My Dung Jusselme, Céline Fosse, Sylvie Derenne

\section{To cite this version:}

Arnaud Huguet, Andre-Jean Francez, My Dung Jusselme, Céline Fosse, Sylvie Derenne. A climatic chamber experiment to test the short term effect of increasing temperature on branched GDGT distribution in Sphagnum peat. Organic Geochemistry, 2014, 73, pp.109-112. 10.1016/j.orggeochem.2014.05.010 . hal-01068383

\section{HAL Id: hal-01068383 https://hal.science/hal-01068383}

Submitted on 25 Mar 2016

HAL is a multi-disciplinary open access archive for the deposit and dissemination of scientific research documents, whether they are published or not. The documents may come from teaching and research institutions in France or abroad, or from public or private research centers.
L'archive ouverte pluridisciplinaire HAL, est destinée au dépôt et à la diffusion de documents scientifiques de niveau recherche, publiés ou non, émanant des établissements d'enseignement et de recherche français ou étrangers, des laboratoires publics ou privés. 


\section{A climatic chamber experiment to test the short term effect of increasing} temperature on branched GDGT distribution in Sphagnum peat

Arnaud Huguet ${ }^{\text {a, b* }}$, André-Jean Francez ${ }^{\text {c }}$, My Dung Jusselme ${ }^{c}$, Céline Fosse ${ }^{\text {d }}$, Sylvie Derenne ${ }^{\mathrm{a}, \mathrm{b}}$

${ }^{a}$ CNRS, UMR 7619, METIS, F-75005, Paris, France

${ }^{\mathrm{b}}$ Sorbonne Universités, UPMC Univ Paris 06, UMR 7619, METIS, F-75005, Paris, France

${ }^{\mathrm{C}}$ Université de Rennes 1, CNRS, UMR 6553, Ecobio, F-35042, Rennes, France

${ }^{\mathrm{d}}$ CNRS-Chimie ParisTech, UMR 8247, IRCP, F-75005, Paris, France

\section{ABSTRACT}

Branched glycerol dialkyl glycerol tetraethers (br GDGTs) are membrane lipids produced by unknown Bacteria and are being increasingly used as temperature proxies. Nevertheless, the direct effect of temperature on br GDGT distributions has been rarely evaluated. In this study, the impact of increasing temperature on brGDGT distributions and the speed of adaptation of br GDGT source microorganisms to temperature change were investigated by analysing br GDGTs in Sphagnum peat cores incubated under controlled conditions at two different temperatures -12 and $15^{\circ} \mathrm{C}$ - for $1 \mathrm{yr}$. Br GDGTs present as intact polar lipids (IPLs, presumably derived from recently active microorganims) and core lipids (CLs, derived from dead biomass) were analysed. There were no significant differences in the relative abundances of the most abundant br GDGTs in the CL and IPL pools after 3 months' incubation. In contrast, the distribution of the br GDGT IPLs was significantly affected by temperature after $1 \mathrm{yr}$, whereas no change was observed in the CL fraction. This suggests that (i) the CL pool of br GDGTs has a turnover of at least $1 \mathrm{yr}$ in peat and (ii) br GDGT source microorganisms rapidly adjust their membrane lipid composition (in $>3$ months and $<1 \mathrm{yr}$, based on IPL analysis).

\footnotetext{
"Corresponding author. Tel: + 33-144-275-172; fax: +33-144-275-150.

E-mail address: arnaud.huguet@upmc.fr (A. Huguet).
} 


\section{Introduction}

Peatlands contain $20-30 \%$ of the world's soil C stock, even though they cover only $3-5 \%$ of the land area (Gorham, 1991). With respect to global climate change, how a moderate temperature rise would affect the organic matter $(\mathrm{OM})$ pool in peat soils and consequently the long term carbon sequestration potential is not known. Peatlands may change from a C sink function to a $\mathrm{C}$ source function. Within the framework of the French ANR project "PEATWARM", the temperature of a pristine Sphagnum-dominated peatland (Frasne, French Jura Mountains) was experimentally increased. The aims were to (i) investigate the impact of a moderate temperature rise on biotic and abiotic compartments of this ecosystem and (ii) more generally determine to which extent this temperature change could modify the $\mathrm{C}$ sink function of temperate peatlands.

We specifically investigated the effect of in situ experimental microclimate warming $(+$ $1.2{ }^{\circ} \mathrm{C}$, mean annual air temperature, MAAT) on branched glycerol dialkyl glycerol tetraether (br GDGT) distribution in the Frasne peatland (Huguet et al., 2013); Br GDGTs (Fig. 1) are membrane lipids produced by unknown bacteria, even though some might belong to the phylum Acidobacteria (Weijers et al., 2009; Sinninghe Damsté et al., 2011). The relative distribution has been shown to depend on environmental parameters; the degree of methylation, expressed in the MBT index, was shown to correlate with MAAT and to a lesser extent with soil $\mathrm{pH}$, whereas the relative abundance of cyclopentyl rings, expressed in the CBT index, was observed to depend on soil pH (Weijers et al., 2007). Over the last few years, an increasing number of studies has focussed on the use of br GDGTs as temperature proxies (Schouten et al., 2013 and references therein). Nevertheless, the direct effect of temperature on br GDGT distribution has been rarely evaluated. Our study of the Frasne peatland showed that br GDGT source microorganisms may rapidly adapt $(<2 \mathrm{yr})$ to an air temperature increase (Huguet et al., 2013). However, additional work is required to further examine the 
effects of temperature on br GDGT distribution and therefore the applicability of br GDGTs as temperature proxies in soils. This is especially true for Sphagnum-dominated peatlands, where microbial communities are sensitive to microclimate change (Jassey et al., 2013).

The aim of this work was to study the impact of a weak temperature increase $\left(3{ }^{\circ} \mathrm{C}\right)$ on br GDGT source microorganisms in a Sphagnum-dominated peatland and their speed of adaptation to temperature change. We used a peat mesocosm experimental device and incubated in controlled conditions intact Sphagnum peat cores from the Frasne peatland. $\mathrm{Br}$ GDGTs present as intact polar lipids (IPLs), presumably derived from recently active microorganims, and core lipids (CLs), - natural hydrolysates of IPLs and thought to derive from dead biomass (White et al., 1979; Harvey et al., 1986), were examined.

\section{Material and methods}

Peat cores $(25 \mathrm{~cm} \times 13 \mathrm{~cm})$ with living vegetation were collected in 2010 from the Frasne peatland, an undisturbed Sphagnum-dominated mire in the French Jura Mountains at $840 \mathrm{~m}$ above sea level. The site is described in detail by Huguet et al. (2013). Briefly, annual precipitation is ca. $1300-1500 \mathrm{~mm} / \mathrm{yr}$ and MAAT measured at the site over the 20082010 period was $6.8^{\circ} \mathrm{C}$. The region is characteriszed by large seasonal temperature variation, with average winter and summer air temperature ca. -1.5 and $16{ }^{\circ} \mathrm{C}$, respectively (Huguet et al., 2013). After 15 days' stabilisation in constant laboratory conditions, the columns (vegetation + underlying peat) were randomly separated into 2 batches: half were incubated at $12{ }^{\circ} \mathrm{C}$ and half at $15{ }^{\circ} \mathrm{C}$ in climatic chambers (Conviron GR96), corresponding to a moderate and realistic rise in temperature according to current modelling scenarii (IPCC 2007). All other environmental conditions were the same (16/8 h day/night photoperiod; daylight conditions $150 \mu \mathrm{mol}$; ambient humidity $80 \%$ ). Each column was placed in a 51 container filled with a poor nutrient source water (Mont-Dore, $\left.\left[\mathrm{HCO}_{3}{ }^{-}\right] 25.8 \mathrm{mg} / \mathrm{l} ; \mathrm{SO}_{4}{ }^{2-}\right] 1.1 \mathrm{mg} / \mathrm{l}$; $\left.\left[\mathrm{NO}_{3}{ }^{-}\right] 0.8 \mathrm{mg} / \mathrm{l}\right)$. The water table level in each container was adjusted to $10 \mathrm{~cm}$ under the 
Sphagnum capitula layer and maintained at that level during the experiment. Therefore, the laboratory conditions of incubation of peat cores were close to the natural conditions in spring and summer in Frasne (Huguet et al., 2013). The br GDGT source microorganisms were previously suggested to be more active in spring and summer than in winter in the peatland (Huguet et al., 2013). Three cores were sampled at the beginning of the experiment in December 2010 and after 3 and 12 months' incubation. The br GDGTs in samples collected under the living Sphagnum layer, between 7 and $12 \mathrm{~cm}$ depth, i.e. roughly at the interface between the acrotelm and catotelm, were analyzed.

Samples were extracted $(3 \times)$ using a modified Bligh and Dyer technique according to Huguet et al. (2013). After solvent evaporation, the extract was separated over a silica gel column into 3 fractions (Huguet et al., 2013): F1 containing apolar lipids, F2 containing CL GDGTs and F3 containing IPL GDGTs. A small aliquot of the IPL fraction (F3) was analysed directly using high performance liquid chromatography-atmospheric pressure chemical ionisation-mass spectrometry (HPLC-APCI-MS) to determine any carryover of CLs into the IPL fraction. The analysis showed nearly complete separation (> 99\%) of the CL and IPL GDGTs. The rest of F3 was subjected to acid methanolysis to cleave off the polar head groups of IPL GDGTs and release the IPL-derived core lipids.

HPLC-APCI-MS analysei was performed with an Agilent 1100 series high performance liquid chromatograph equipped with an automatic injector coupled to a PE Sciex API 3000 mass spectrometer. GDGTs were analysed using the procedure described by Huguet et al. (2013). The MBT' was calculated as follows (Peterse et al., 2012; Eq. 1), with roman numbers referring to GDGT structures displayed in Fig. 1:

$$
M B T^{\prime}=\frac{[I a+I b+I c]}{[I a+I b+I c]+[I I a+I I b+I I c]+[I I I a]}
$$

The CBT was calculated according to the equation developed by Weijers et al. (2007; Eq. 2): 


$$
C B T=-\log \left(\frac{[I b]+[I I b]}{[I a]+[I I a]}\right)
$$

MAAT was estimated from the MBT' and CBT indices using the extended soil calibration introduced by Peterse et al. (2012; Eq. 3):

$$
M A A T=0.81-5.67 \times C B T+31.0 \times M B T^{\prime}
$$

The differences induced by the incubation treatment, in terms of br GDGT distribution and abundance, were analyzed using the $t$-test (Microsoft Excel Analysis ToolPak). Statistical significance was considered as $p<0.05 ; p$ values between 0.05 and 0.010 were considered as indicating a trend.

\section{Results and discussion}

The absolute and relative abundances of br GDGTs were determined in the CL and IPL fractions of all peat samples (Table 1). The concentrations of br GDGT CLs and IPLs did not show any significant differences between the 2 temperature treatments after 3 and 12 months' incubation (Table 1). This showed that there was no obvious effect of a moderate increase in ambient temperature $\left(3^{\circ} \mathrm{C}\right)$ on br GDGT abundance and production, as previously observed after the simulation of a moderate temperature rise using passive warming systems in the field (open top chambers; OTCs) in the Frasne peatland (Huguet et al., 2013). The concentration of br GDGT CLs during the incubation experiment ranged between ca. 9 and $17 \mu / g$ dry peat and were comparable to those for peat samples collected at the same site and at the same depth in April 2008 (ca. 15-17 $\mu \mathrm{g} / \mathrm{g}$ ) and June 2010 (ca. $10 \mu \mathrm{g} / \mathrm{g}$; Huguet et al., 2013). The proportion of br GDGT IPLs was slightly higher in the samples incubated for 3 months at 15 ${ }^{\circ} \mathrm{C}$ than at $12{ }^{\circ} \mathrm{C}$. Except for this, there was no major difference in the relative abundance of br GDGT CLs and IPLs between the samples collected at the beginning and at the end of the experiment, the proportion of br GDGT CLs, with respect to the total pool (i.e. CL + IPL) of br GDGTs, comprising between ca. 80 and 90\% (Table 1). This indicates that br GDGTs were 
derived predominantly from dead biomass, consistent with previous observations in peat and soils (e.g. Weijers et al., 2009; Huguet et al., 2013).

The br GDGTs Ia and IIa were largely predominant in the CL and IPL fractions of all samples, representing respectively ca. $40-55 \%$ and $35-40 \%$ of total br GDGTs (Table 1). GDGTs IIIb and IIIc were not detected in any of the samples, implying that MBT and MBT' values were identical. There was no significant effect of increasing temperature on the relative abundances of the most abundant brGDGTs (Ia, IIa and IIIa) as well as on the MBT' and CBT values after 3 months, for both CLs and IPLs (Table 1). In addition, the relative abundances of the main br GDGTs, as well as the MBT' and CBT values, were comparable between the samples collected at the beginning (control) and after 3 months' incubation, for both the CL and IPL pools $(\mathrm{p}>0.1)$. This suggests that br GDGT source microorganisms may require $>3$ months for adapting to temperature changes, at least at the peat surface.

The analysis of CLs revealed no significant differences in the relative abundances of the most abundant br GDGTs and the MBT' and CBT between the samples incubated at $12{ }^{\circ} \mathrm{C}$ and $15{ }^{\circ} \mathrm{C}$ after $1 \mathrm{yr}$ (Table 1). In contrast, the distribution of the br GDGT IPLs was significantly affected by the difference in incubation temperature after $1 \mathrm{yr}$, as shown by the higher and lower abundances of Ia and IIIa at $15{ }^{\circ} \mathrm{C}$ than at $12{ }^{\circ} \mathrm{C}$, respectively (Table 1). This was also reflected in the MBT' index, which was significantly higher at $15^{\circ} \mathrm{C}$ than at $12{ }^{\circ} \mathrm{C}$, consistent with the empirical relationship between br GDGT distribution and air temperature established for soil (Weijers et al.., 2007; Peterse et al., 2012), with higher MBT' values at higher temperature. Taken together, the incubation results suggest that the turnover time of br GDGT IPLs is $>3$ months but $<1 \mathrm{yr}$. IPLs are assumed to derive from living microorganisms and to degrade rapidly to CLs when their source organism dies (White et al., 1979; Harvey et al., 1986), implying that the turnover time of IPLs is likely faster than that of CLs and that the complete renewal of the CL pool takes more time than that of the IPL pool. It may be 
assumed that the turnover time of the br GDGT CL distribution is $>1 \mathrm{yr}$ in peat, consistent with the fact that no significant changes in br GDGT CL distribution were observed after 12 months. This can in turn explain why the MAAT estimates derived from br GDGT CLs were not affected by the incubation and were, even after $1 \mathrm{yr}$, similar to the reconstructed MAAT value obtained at the beginning of the experiment (ca. $10{ }^{\circ} \mathrm{C}$; Fig. 2). This value is slightly higher than the instrumentally recorded MAAT in the Sphagnum peat (ca. $7^{\circ} \mathrm{C}$ ) and could reflect spring and summer (ca. $11^{\circ} \mathrm{C}$ ) rather than annual air temperature (Huguet et al., 2013), even though it is still within the standard error of the MBT'-CBT-MAAT calibration $( \pm 4.8$ ${ }^{\circ} \mathrm{C}$; Peterse et al., 2012). In contrast to the $\mathrm{CL}$ pool, the effect of the incubation time on the distribution of br GDGT IPLs was also reflected in the temperature estimates (Fig. 2): after 1 yr treatment, the reconstructed temperature for an incubation temperature of $15^{\circ} \mathrm{C}(10.2 \pm 1.3$ $\left.{ }^{\circ} \mathrm{C}\right)$ was slightly higher than the values for an incubation temperature of $12{ }^{\circ} \mathrm{C}\left(8.5 \pm 0.6{ }^{\circ} \mathrm{C}\right)$.

We recently showed that the turnover time of br GDGT CLs is $<2 \mathrm{yr}$ at the peat surface, based on a similar br GDGT distribution in the CL and IPL pools after $2 \mathrm{yr}$ of in situ warming treatment in the Frasne peatland (Huguet et al., 2013). These results, combined with those of the present study, suggest that (i) br GDGT source microorganisms rapidly adjust their membrane lipid composition (in $>3$ months and $<1 \mathrm{yr}$ based on IPL analysis) to temperature change and that (ii) the fossil pool of br GDGTs (i.e. CLs) has a turnover of a least 1 yr but < $2 \mathrm{yr}$ in peat environments. Weijers et al. (2010) estimated the turnover of br GDGTs to be ca. $20 \mathrm{yr}$ in two arable soils, and Peterse et al. (2010) to be $<45 \mathrm{yr}$ according to br GDGT analysis in long term soil $\mathrm{pH}$ manipulation plots. Therefore, all these studies, including ours, suggest that br GDGTs turn over on timescales of decades. This has to be confirmed by investigating the turnover of br GDGTs, and more generally the rapidity of adaptation of br GDGT source microorganisms to environmental change, in soils from all over the world.

\section{Acknowledgments}


This paper is a contribution of the PEATWARM project (Effect of moderate warming on the functioning of Sphagnum peatlands and their functions as a carbon sink) financially supported by the French National Agency (ANR-07-VUL-10). We thank the anonymous reviewer for comments.

\section{Associate Editor - P. Schaeffer}

\section{References}

Gorham E. (1991) Northern peatlands: role in carbon cycle and probable responses to climate warming. Ecological Applications 1, 182-195.

Harvey, H. R., Fallon, R. D., Patton, J. S., 1986. The effect of organic matter and oxygen onthe degradation of bacterial membrane lipids in marine sediments. Geochimica et Cosmochimica Acta 50, 795-804.

Huguet, A., Fosse, C., Laggoun-Défarge, F., Delarue, F., Derenne, S., 2013. Effects of a short-term experimental microclimate warming on the abundance and distribution of branched GDGTs in a French peatland. Geochimica et Cosmochimica Acta 105, 294-315.

I.P.C.C. 2007. Climate Change 2007: the physical Science Basis. Cambridge University Press, Cambridge 996 pp.

Jassey, V.E.J., Chiapusio, G., Binet, P., Buttler, A., Laggoun-Défarge, F., Delarue, F., Bernard, N., Mitchell, E.A.D., Toussaint, M.-L., Francez, A.-J., Gilbert, D. 2013. Aboveand below ground linkages in Sphagnum-peatland: climate warming affects plantmicrobial interactions. Global Change Biology 19, 811-823.

Peterse, F., Nicol, G. W., Schouten, S., Sinninghe Damsté, J. S., 2010. Influence of soil pH on the abundance and distribution of core and intact polar lipid-derived branched GDGTs in soil. Organic Geochemistry 41, 1171-1175.

Peterse, F., van der Meer, J., Schouten, S., Weijers, J.W.H., Fierer, N., Jackson, R.B., Kim, J.H., Sinninghe Damsté, J.S., 2012. Revised calibration of the MBT-CBT paleotemperature proxy based on branched tetraether membrane lipids in surface soils. Geochimica et Cosmochimica Acta 96, 215-229.

Schouten, S., Hopmans, E.C., Sinninghe Damsté, J.S., 2013. The organic geochemistry of glycerol dialkyl glycerol tetraether lipids: A review. Organic Geochemistry 54, 19-61.

Sinninghe Damsté, J.S., Rijpstra, W.I.C., Hopmans, E.C., Weijers, J.W.H., Foesel, B.U., Overmann, J., Dedysh, S.N., 2011. 13,16-Dimethyl octacosanedioic acid (iso-diabolic acid), a common membrane-spanning lipid of Acidobacteria subdivisions 1 and 3. Applied and Environmental Microbiology 77, 4147-4154.

Weijers, J.W.H., Schouten, S., van den Donker, J.C., Hopmans, E.C., Sinninghe Damsté, J.S., 2007. Environmental controls on bacterial tetraether membrane lipid distribution in soils. Geochimica et Cosmochimica Acta 71, 703-713.

Weijers, J.W.H., Panoto, E., van Bleijswijk, J., Schouten, S., Rijpstra, W.I.C., Balk, M., Stams, A.J.M., Damsté, J.S.S., 2009. Constraints on the biological source(s) of the orphan branched tetraether membrane lipids. Geomicrobiology Journal 26, 402-414.

Weijers, J.W.H., Wiesenberg, G.L.B., Bol, R., Hopmans, E.C., Pancost, R.D., 2010. Carbon isotopic composition of branched tetraether membrane lipids in soils suggest a rapid turnover and a heterotrophic lifestyle of their source organism(s). Biogeosciences 7, 2959-2973.

White, D. C., Davis, W. M., Nickels, J. S., King, J. D., Bobbie, R.J., 1979. Determination of the sedimentary microbial biomass by extractable lipid phosphate. Oecologia 40, 51-62. 
Fig. 1. Structures of br GDGT membrane lipids and internal standard (IS).

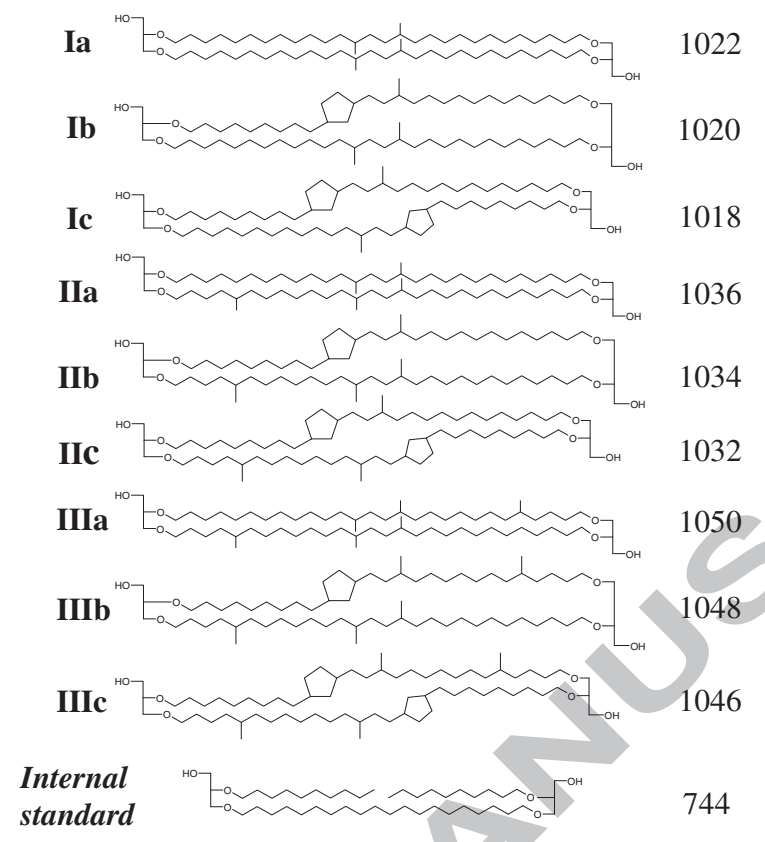

Fig. 2. Mean values and standard errors of MBT'/CBT-derived temperature for peat samples before and during incubation under controlled conditions $(\mathrm{n}=3)$ at $12{ }^{\circ} \mathrm{C}$ and $15{ }^{\circ} \mathrm{C}$. Temperature estimates are reported for (a) the CL and (b) the IPL fraction, respectively.
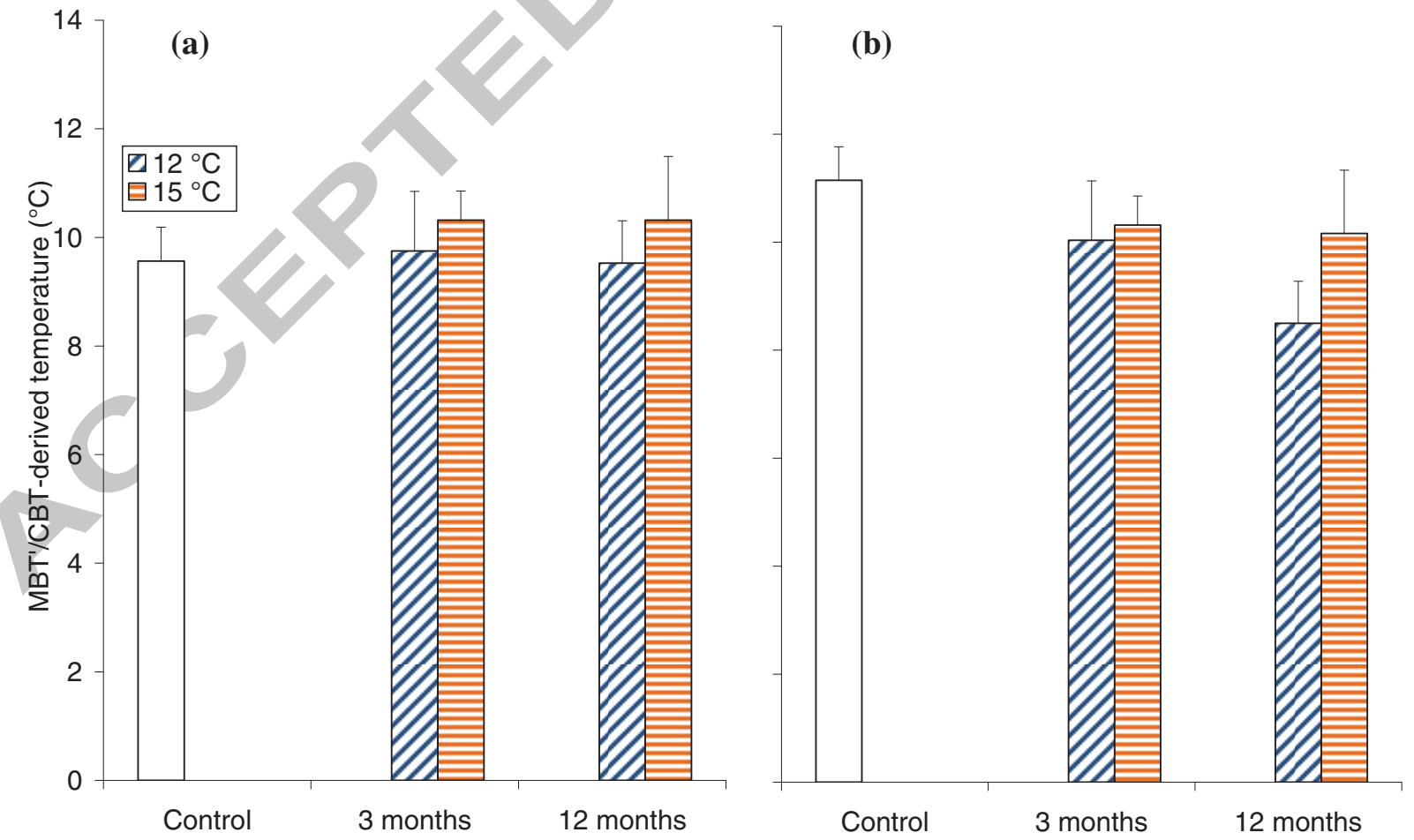


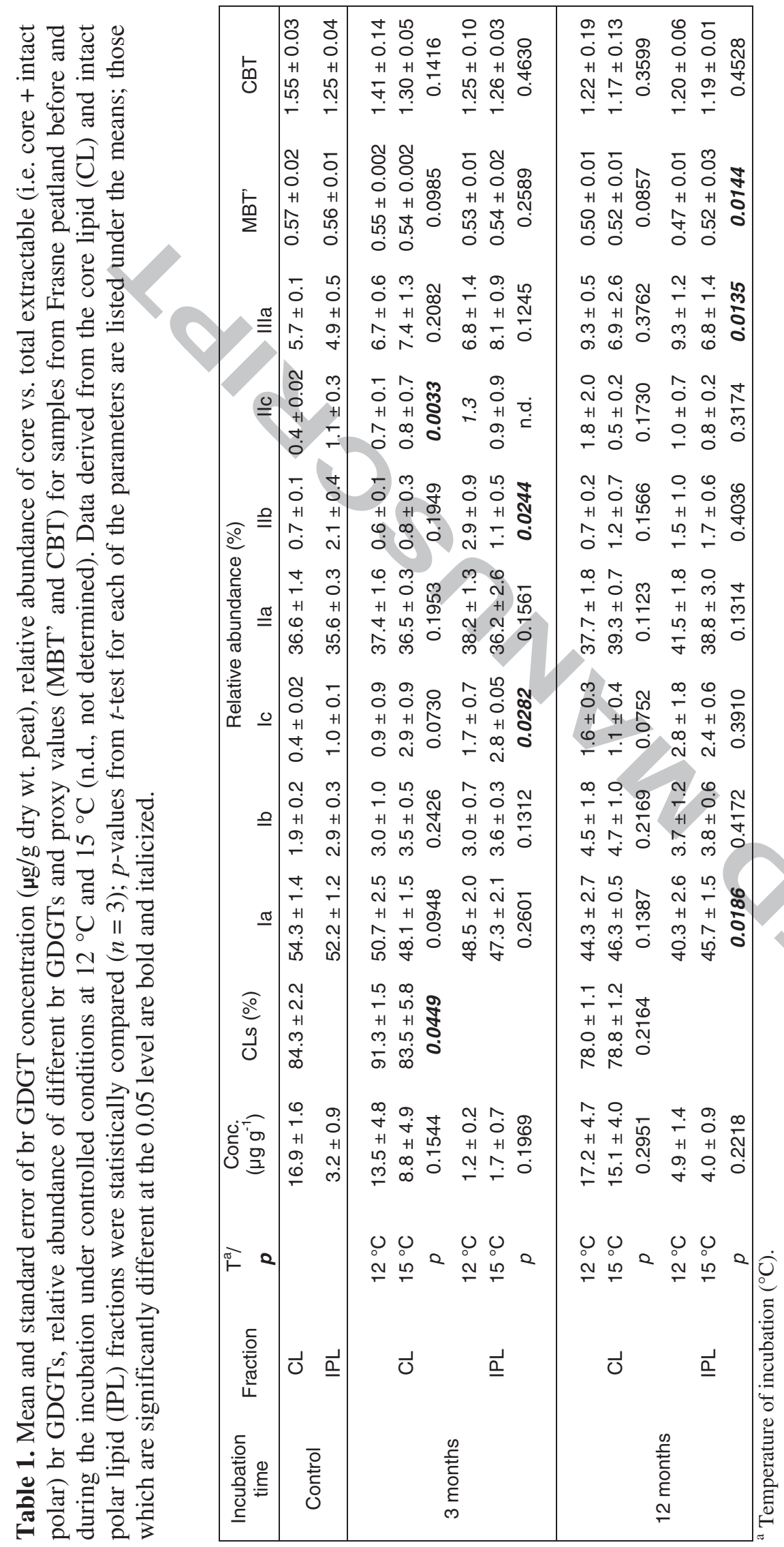

